\title{
Àrẹ Lekan Àrẹ: A Tribute to a Warrior for all Battles
}

Toyin Falola

The University of Texas at Austin

toyinfalola@austin.utexas.edu

\author{
In the forest of songs \\ yours is a fertile lyric \\ weaved for every ear. \\ In the sky of words \\ your lines are rainbow, \\ brighter than the moon, \\ illuminating beyond the \\ stars. Àrẹ, now that the \\ flute of death blew beyond the seven hills \\ of İbàdàn, I offer an \\ elegy to the man whose \\ impacts shaped our lives, \\ a man whose anvil forged the future we \\ desired. Àjana kú, the \\ elephant that rumbles \\ the forest. If death would \\ have loved to receive money, we would have \\ offered him money. \\ If death would have loved \\ to be offered a thousand \\ rams, we would have loved to slaughter them. \\ But death took you, \\ beyond the earth where \\ the feet of children learn \\ to walk without stumbling. \\ You-father, mentor. \\ You-Achiever. Catalyst.
}


Before the advent of the

media, your words travelled beyond the

four walls of our country.

Before the arrival of death, you were the king

and Elẹ́sin Oba. You made the earth look

ordinary. Now that the

song of farewell occupies the sky,

Àrẹ, let my elegy adorn

the world. Today there

are no birds to sing

because of your demise.

Today the earth trembles

because your death broke the camel's hump.

Ọmọ İbàdàn, your lineage

is that of a warrior. Your

memory remains unbroken despite the

tenacity of time.

Farewell, the mountain that bends the arrow of lies.

Farewell, the rain that veils deserted lands.

Farewell to the son

of the soil.

Farewell to the scion

of İbàdàn.

Let me now shift gears to the tedium of history. The late Dr. Lekan Àre (1933-2020) was the founder and Chief Executive (CEO), Kakanfo Inn and Conference Centre, İbàdàn. He was also the chairman, University Press Plc., former General Manager, Ogun-Osun River Basin Authority, and the longest-serving director on the board of Punch Nigeria Limited. The late Àre was a member of İbàdàn Elders Forum and a strong pillar of Government College, İbàdàn Old Boys Association (GCIOBA). The president, Government College İbàdàn Old Boys Association (GCIOBA), Chief Wale Babalakin, in a statement, said: "With gratitude to God for a life well spent we announce the exit of our dear patron and trustee, Lalekan Emmanuel Àrẹ (1948, Field House), President GCIOBA 1989-2006. Lekan Àre is widely known for the passion with which he championed the GCI cause and everything GCIOBA, Lalekan Àre was the epitome of a great Old Boy."

Chief Lekan Àrẹ will be remembered as an Afrophile, a custodian of the Yorùbá culture and a multiculturalist. In his lifetime, he portrays the knowledge of the continent which includes engrained familiarity with different myths, folktales and socio-cultural belief in Nigeria and Africa as well. Also, 
in his engagement with Africa, Chief Àre extends his representations of the continent to its people. He deconstructs earlier notions that majority of Africans flux into the West without a sense of purpose. He is a grand believer of Africans having a sense of purpose and rooted in culture where they come from.

His ideas and ways of living was that of the Afropolitan, one who believes that in spite of their culturally hybrid nature, one does not sever ties and relationship with one's African roots. Often times, he has illustrated this attitude with his narration of the story of one of his family members who married a Japanese. The family not only maintains contact with the Yorùbá culture, they transmit both Yorùbá and Japanese customs to their children too. A humanist and an accommodator of culturally different people, he always insists that there are people who seek to be understood beyond the rigid limits of their statehood. Hence, an affiliation to a country should hardly be the basis for understanding a human being in their totality. This worldview is well espoused in the story of how he travelled to Brazil and met Yorùbá indigenes with whom he bonded passionately. Even though he is a firm displayer of the Yorùbá culture, he also demonstrates a flair for cultural intermingling and interpenetration both within and outside the continent. As a major proponent of interracial mingling and inclusion, Chief Lekan Àrẹ gives primacy to interracial marriages and interethnic relationships. He is also reputed for encouraging Africans to always place cultural communality over the divisiveness of religious difference.

Àrẹ Lineage in Different Ages

Jàgíní! Jàgíní!

Ojú inú, I can see! I can see!

Images tell their lore

Like the moon contrasts the grey of the sky

Unveiling, revealing, unwrapping

Ancient text on woven formats

Once seen through a glass darkly

Unmask hidden forms

Ifá, Arínúróde!

I can see! I can see!

The Àrẹ lineage of İbàdàn has created a most impressive historical narrative over time. In the old era of the 19th century, they were great warriors, with one of them-Àre Latosa-rising to become the ultimate political leader of the city and the overall Generalissimo of the Yorùbá. Àrẹ Latoosa was famous for the greater part of the nineteenth century, and was actually the most 
powerful in the last quarter of that turbulent era. The Àrẹ managed a huge İbàdàn empire at a time of relentless and coordinated opposition from multiple corners and sources. Oba I. B. Akinyele, who wrote a book in 1951, İwé İtàn İbàdàn, on the history of İbàdàn documenting this era, paid scholarly attention to the tènbẹlẹkun and ọtẹ, the nasty twin of intrigues and conspiracies that defined this era. Thus, as the empire made the Àre face ogun (war) abroad, there were tẹnbẹlẹk $u n$ and ọtẹ at home also, and there were just too many of them for one person to manage. Samuel Johnson who also recorded that moment painted a picture of actions, complicated decision making, rivalries, and difficult conflict management efforts. The Àrẹ was able to stand at the center of it all. The empire and its leader dominated the events. Samuel Johnson wrote under the shadow of the İbàdàn empire. His composition and portrait of the Àre used the language of the empire-muscular, imperial, dominating.

As I fell on the past of the distinguished Àre lineage, I composed a new song:

\section{Omọkùnrin kànkà,}

the hen who challenges the vulture

$$
\text { to a fight }
$$

The vulture circles the hen

Smiling, the hen teases the vulture:

Become a hawk if you want to eat me

Or wait for my death to eat the carcass

What can the vulture do to a hen?

What can enemies do to the Àrẹ Onà Kakan'fo'?

The war hawk of İbàdàn

A wildfire that stays on the roof

Daring the landlord to fetch fire Water comes, Okùnrinméta turns into air

Air, the husband of fire

Ekiti take flight

Àre jumps thrice to retool.

Ológun, yan, yan, yanbíakin

The war captain of İbàdàn

Summoning the omọ Odùduwà with a command;

Arm yourselves for battle in the morning

I, Yanbíolá, the war general

Who sleeps outside until the war is over. 
Àrẹ, Àrẹ, Àrẹ

Never tired of wars, he roams the world

The restless spirit of İbàdànland

Ògún ọmọ Ogun

Àre I am scared

Spare me!

Yan, yan, Yanbiólá

Wait for him if you dare!

The offspring of a compound

Full of arrows

Are the offspring of a thousand quivers

Yanbíolá, never tired of wars.

Àrẹ was thirsty

As his thirst rumbles

The River Niger trembles

Àre, he that pours water away

On hearing the rumbling of the rain

When the rain rumbles and refuses to fall

Yanbíolá turns the Nile into a big pot

To supply water to the city.

If the rain so chooses

Let it never fall again.

The late Chief Lalekan Àre extended the glory of the lineage, carrying the genes of the older members of the lineage. He added positively to them in aspects of business, management, administration, institutional leadership, and community organizing. His mantra was hard work, analysis based on facts, the correlation of process with outcome, judicious use of resources, empathy and compassion. The foundation of his life and career was laid many decades ago. As a young man in the grammar school and university, he combined excellence in sports with distinction in scholarship.

Dr. Lalekan Àrẹ's style shared many things in common with the warriors of old. He was a straight shooter, although not of guns but of words. Quick to the point, forever dramatic in his actions and choice of words, and very witty, Dr. Àre was effective in getting to the bottom of issues and taking decisions based on facts and good judgment. Like his ancestors, he was a fearless warrior. His weapons extended to the realm of ideas and ideologies. A warrior for all battles, he courageously took up for many issues with extensive social and political import. 


\section{Àlàmú, ọmọ Níhìnlọla} Mo pè yín l'órúko

Oh, spirit of the hills!

Rise up, oh warrior, rise up Tough and stubborn, Bảbá kan șoṣo

The fearless, never bothered by threats

Baba hears, Run! Run! Run!-he refuses to run Baba hears, Give way! Give way! - he refuses to relent.

Tactful warrior, offspring of the Great Warrior

Okọọ Ọábísí who challenges death.

Death carries a club,

Baba Fúnkẹ carries a club.

Elephants and lions take flight.

He who witnesses Baba Ayọ and Death in

a duel does not live to tell the story.

Àlàmú, expose the treacherous - treachery

hides.

Baba Dàmọlá, show the face of the wicked:

wickedness hides.

The hyena who roams the jungle, taunting

the dogs to emulate him.

Gently! Gently! Baba àgbà.

Please! Conqueror of death. we think no evil, speak no evil

Hear no evil of Baba wa

I will first sacrifice to Bàbá Àrẹ

Conqueror of Death

Before I sacrifice to Òke'bàdàn

Lord of the Hills

Òke’bàdàn can wait, Bàbá cannot

Accept my kola

Bless my kola to multiply

May I never see the wrath of Baba

Only his praises.

Rats see the cat and run.

Baba Revenge! Revenge!

not once, but twice

For they who scheme evil against you yesterday morning

Àrẹ dead by day break. 
Baba, Lord of the land and sea

Five men in one, never to be subdued,

Tiger of the plain,

Baba, chew silently

to say your incantations

Grind on the thick stone

to make your charms

Open your mouth

to sing

Clear your legs

to dance.

Ẹkùn,

Praise us, when you mean it abuse us when we deserve it.

We bend and bow

to avoid the fiery eyes

We prostrate

to avoid eyes of blood

We are quiet

to avoid the tongue that lashes

We appease İyálóde

to calm your temper.

I am a beneficiary of his large mind and grandiose generosity. Although I have not been able to take him up on the offer, he mandated his staff to let me stay at Kakanfo Inn for free any time I am around. He funded the publication of my long book on İbàdàn. May the Àrẹ of the future be great men and women of heroic characters like the Àrẹ of the past. May the Àrẹ of the future be great entrepreneurs and investors as the Àrẹ of the present. As we celebrate the departed soul, do please join me in dancing to a new song:

He watches our war steps

We, who never run away from death

We wage wars at four corners of the house

We told him the four:

The bow carrier in front

The quiver carrier in the middle

The arrow carrier stays to the left

The gun carrier at the back.

Lekan, master of our moves.

Àrẹ turns into an Egbinrín 
Egbinrin, creator of colors

Offspring of the slim İrókòo tree

Master of clothes

If there were no cloth

We would have misbehaved

Laughing tirelessly,

Egbinrin would have offered the feathers

For us to fool the world.

Àre is reborn

Reborn into wealth

If you are pursued by death

It will not catch up with you,

Eat Kola, the nut of life

The bitter kola that elongates life

May you live long

Eat sugarcane,

The sweetness of life

You will live a sweet life

Drink water

No one chooses water as an enemy

May you become water

Water that has no enemies.

Baba mi, the good

Who is grateful for favors

On the bad, a thousand favors

are wasted.

A fit man with

Ears for wise sayings

Head for counseling

Brain for ideas

Chief Lálẹkan Àrẹ, serve no fools

Who weep in the wilderness

Who plant lotus on dry land

Baba mi àgbàlagbà oyè,

The water with no enemies.

And after the dance, let us close with a final meditation:

Somewhere young turned old gents

Will handle a photo album with fragile fingers

And its dust will turn breathable air,

Old dreams, wise words will grace wrinkled faces 
As silence breaks into sweet single tears

While they sniff the nostalgic smell Of your youthful posture

In black and white

Àjànàkú ńlá, we will see life the way

It is meant to be

An assemblage of your youthful bravery actions,

Wise words and old age pictures

Which will be imagined through the eyes

Of living old men

Who were once lads sitting at your

Feet that walked this earth...

I remember when waters were clear

death was not a word

nor sorrow ever heard

we bathed in milky lakes

doves skimming an infinite blue

something lived on...

Chief, your actions are living on. 